\title{
Front Matter: Volume 6498
}

, "Front Matter: Volume 6498," Proc. SPIE 6498, Computational Imaging V, 649801 (16 March 2007); doi: 10.1117/12.729178

SPIE. Event: Electronic Imaging 2007, 2007, San Jose, CA, United States 


\section{PROCEEDINGS OF Electronic Imaging \\ Science and Technology}

\section{Computational Imaging $V$}

Charles A. Bouman

Eric L. Miller

llya Pollak

Editors

29-31 January 2007

San Jose, California, USA

Sponsored and Published by

IS\&T-The Society of Imaging Science and Technology

SPIE-The International Society for Optical Engineering 
The papers included in this volume were part of the technical conference cited on the cover and title page. Papers were selected and subject to review by the editors and conference program committee. Some conference presentations may not be available for publication. The papers published in these proceedings reflect the work and thoughts of the authors and are published herein as submitted. The publishers are not responsible for the validity of the information or for any outcomes resulting from reliance thereon.

Please use the following format to cite material from this book:

Author(s), "Title of Paper," in Computational Imaging V, edited by Charles A. Bouman, Eric L. Miller, Ilya Pollak, Proceedings of SPIE-IS\&T Electronic Imaging, SPIE Vol. 6498, Article CID Number (2007).

ISSN 0277-786X

ISBN 9780819466112

Copublished by

SPIE-The International Society for Optical Engineering

P.O. Box 10, Bellingham, Washington 98227-0010 USA

Telephone 1 360/676-3290 (Pacific Time) · Fax 1 360/647-1445

http://www.spie.org

and

IS\&T-The Society for Imaging Science and Technology

7003 Kilworth Lane, Springfield, Virginia, 22151 USA

Telephone 1 703/642-9090 (Eastern Time) · Fax 1 703/642-9094

http://www.imaging.org

Copyright (C) 2007, The Society of Photo-Optical Instrumentation Engineers and The Society for Imaging Science and Technology.

Copying of material in this book for internal or personal use, or for the internal or personal use of specific clients, beyond the fair use provisions granted by the U.S. Copyright Law is authorized by SPIE and IS\&T subject to payment of copying fees. The Transactional Reporting Service base fee for this volume is $\$ 18.00$ per article (or portion thereof), which should be paid directly to the Copyright Clearance Center (CCC), 222 Rosewood Drive, Danvers, MA 01923. Payment may also be made electronically through CCC Online at http://www.copyright.com. Other copying for republication, resale, advertising or promotion, or any form of systematic or multiple reproduction of any material in this book is prohibited except with permission in writing from the publisher. The CCC fee code is 0277$786 \times / 07 / \$ 18.00$.

Printed in the United States of America. 


\section{Contents}

ix Conference Committee

\section{SESSION 1 MEDICAL IMAGING I}

649803 Analysis of reconstructions in full view fluorescence molecular tomography [6498-01] D. Hyde, A. Soubret, J. Dunham, T. Lasser, E. Miller, D. Brooks, V. Ntziachristos, Northeastern Univ. (USA), Tufts Univ. (USA), and Massachusetts General Hospital, Harvard Medical School (USA)

649804 Image reconstruction for small animal SPECT with two opposing half cones [6498-02] Y. Zheng, Univ. of Virginia (USA); H. Li, Univ. of Texas (USA); J. Wang, A. V. Stolin, J. Pole, M. B. Williams, Univ. of Virginia (USA)

649805 Regularized reconstruction of dynamic gated cardiac SPECT images [6498-03] M. Jin, Y. Yang, Illinois Institute of Technology (USA)

649806 Image reconstruction performance as a function of model complexity using information geometry: application to transmission tomographic imaging [6498-04]

J. A. O'Sullivan, L. Xie, Washington Univ. (USA); D. G. Politte, B. R. Whiting, Washington Univ. School of Medicine (USA)

\section{SESSION 2 MOSAICING, INTERPOLATION, SUPER-RESOLUTION}

649807 Creating panoramas on mobile phones [6498-05]

J. J. Boutellier, M. Bordallo-Lopez, O. Silvén, Univ. of Oulu (Finland); M. Tico, M. Vehviläinen, Nokia Research Ctr. (Finland)

Pagination: Proceedings of SPIE follow an e-First publication model, with papers published first online and then in print and on CD-ROM. Papers are published as they are submitted and meet publication criteria. A unique, consistent, permanent citation identifier (CID) number is assigned to each article at the time of the first publication. Utilization of CIDs allows articles to be fully citable as soon they are published online, and connects the same identifier to all online, print, and electronic versions of the publication.

SPIE uses a six-digit CID article numbering system in which:

- The first four digits correspond to the SPIE volume number.

- The last two digits indicate publication order within the volume using a Base 36 numbering system employing both numerals and letters. These two-number sets start with 00, 01, 02, 03, 04, 05, 06, 07, 08, 09, 0A, OB ... 0Z, followed by 10-1Z, 20-2Z, etc.

The CID number appears on each page of the manuscript. The complete citation is used on the first page, and an abbreviated version on subsequent pages. 
649808 Multidimensional image enhancement from a set of unregistered differently exposed images [6498-06]

A. A. Rad, L. Meylan, P. Vandewalle, S. Süsstrunk, École Polytechnique Fédérale de Lausanne (Switzerland)

649809 Graph-based multiple panorama extraction from unordered image sets [6498-07]

A. Sibiryakov, M. Bober, Mitsubishi Electric ITE B.V. (United Kingdom)

64980A Image interpolation using multiscale geometric representations [6498-08]

N. Mueller, Y. LU, M. N. Do, Univ. of Illinois at Urbana-Champaign (USA)

SESSION 3 SEGMENTATION AND SHAPE ANALYSIS

64980D 4D segmentation of cardiac data using active surfaces with spatiotemporal shape priors [6498-11]

A. Abufadel, T. Yezzi, Georgia Institute of Technology (USA); R. Schafer, Hewlett-Packard Labs. (USA)

64980E Automated segmentation of alloy microstructures in serial section images [6498-12]

J. M. Dumke, M. L. Comer, Purdue Univ. (USA)

64980F Fast Mumford-Shah segmentation using image scale space bases [6498-13]

C. V. Alvino, A. J. Yezzi, Georgia Institute of Technology (USA)

\section{SESSION 4 COMPRESSION AND COMPRESSED SENSING}

64980G Shape representation via conformal mapping [6498-14]

M. Feiszli, D. Mumford, Brown Univ. (USA)

64980 The smashed filter for compressive classification and target recognition [6498-15]

M. A. Davenport, M. F. Duarte, Rice Univ. (USA); M. B. Wakin, California Institute of

Technology (USA); J. N. Laska, D. Takhar, K. F. Kelly, R. G. Baraniuk, Rice Univ. (USA)

64980J Variational methods for compressive sampling [6498-17]

J. Romberg, Georgia Institute of Technology (USA)

64980K Compression of noisy Bayer pattern color filter array images [6498-18]

V. V. Lukin, N. N. Ponomarenko, National Aerospace Univ. (Ukraine); A. V. Bazhyna,

K. O. Egiazarian, Tampere Univ. of Technology (Finland)

64980L Multiscale reconstruction for computational spectral imaging [6498-19]

R. M. Willett, Duke Univ. (USA); M. E. Gehm, Univ. of Arizona (USA); D. J. Brady, Duke Univ.

(USA)

\section{SESSION 5 HARDWARE SYSTEMS FOR IMAGING AND TOMOGRAPHY}

$64980 \mathrm{~N}$ Why do commodity graphics hardware boards (GPUs) work so well for acceleration of computed tomography? (Keynote Paper) [6498-20]

K. Mueller, F. Xu, N. Neophytou, Stony Brook Univ. (USA) 
64980P Tomographic image reconstruction using the cell broadband engine (CBE) general purpose hardware [6498-22]

M. Knaup, S. Steckmann, Univ. of Erlangen-Nürnberg (Germany); O. Bockenbach, Mercury

Computer Systems GmbH (Germany); M. Kachelrieß, Univ. of Erlangen-Nürnberg

(Germany)

64980Q Iterative reconstruction of cone-beam CT data on a cluster [6498-23]

T. M. Benson, GE Global Research (USA); J. Gregor, The Univ. of Tennessee, Knoxville (USA)

64980R Evolution of computer technology for fast cone-beam backprojection [6498-51]

I. Goddard, A. Berman, Mercury Computer Systems, Inc. (USA); O. Bockenbach, Mercury

Computer Systems GmbH (Germany); F. Lauginiger, Mercury Computer Systems, Inc. (USA);

S. Schuberth, Mercury Computer Systems GmbH (Germany); S. Thieret, Mercury Computer

Systems, Inc. (USA)

SESSION 6 RESTORATION, FILTERING, AND RECONSTRUCTION

64980S Higher order bilateral filters and their properties [6498-24]

H. Takeda, S. Farsiu, P. Milanfar, Univ. of California, Santa Cruz (USA)

64980T The use of levelable regularization functions for MRF restoration of SAR images while preserving reflectivity [6498-25]

J. Darbon, Univ. of California, Los Angeles (USA) and EPITA (France); M. Sigelle, F. Tupin,

École Nationale Supérieure des Télécommunications (France)

$64980 U$ Nonlocal evolutions for image regularization [6498-26]

G. Gilboa, S. Osher, Univ. of California, Los Angeles (USA)

64980V Parametric point spread function modeling and reduction of stray light effects in digital still cameras [6498-27]

B. Bitlis, Purdue Univ. (USA); P. A. Jansson, College of Optical Sciences, The Univ. of Arizona (USA); J. P. Allebach, Purdue Univ. (USA)

64980W An image decomposition model using the total variation and the infinity Laplacian [6498-28]

C. Elion, L. A. Vese, Univ. of California, Los Angeles (USA)

SESSION 7 TRACKING, RECOGNITION, AND SCENE ANALYSIS

64980Y Symmetry detection in 3D scenes [6498-30]

T. Sawada, Z. Pizlo, Purdue Univ. (USA)

$64980 Z$ Object recognition via information: theoretic measures/metrics [6498-31]

D. W. Repperger, A. R. Pinkus, Air Force Research Lab. (USA); J. A. Skipper, C. D. Schrider, Wright State Univ. (USA)

SESSION 8 MULTIGRID METHODS

649810 Multigrid optimal mass transport for image registration and morphing [6498-32]

T. u. Rehman, A. Tannenbaum, Georgia Institute of Technology (USA) 
649811 The effect of intergrid operators on multigrid convergence [6498-33]

P. Navarrete, Purdue Univ. (USA) and Univ. de Chile (Chile); E. J. Coyle, Purdue Univ. (USA)

SESSION 9 IMAGING IN MATERIALS SCIENCE

649812 Using transmission electron microscopy to quantify the spatial distribution of nanoparticles suspended in a film [6498-34]

S. Newsam, E. Pernice, J. Jasinski, V. Leppert, Univ. of California, Merced (USA)

SESSION 10 RECONSTRUCTION, INPAINTING, AND PREDICTION

649813 Image inpainting based on energy minimization [6498-35]

N. Kawai, T. Sato, N. Yokoya, Nara Institute of Science and Technology (Japan)

649814 Signal reconstruction from a periodic nonuniform set of samples using $\boldsymbol{H}_{\text {罾 }}$ optimization [6498-36]

Ha. T. Nguyen, M. N. Do, Univ. of Illinois at Urbana-Champaign (USA)

649815 A multiscale statistical model for time series forecasting [6498-54]

W. Wang, I. Pollak, Purdue Univ. (USA)

\section{SESSION 11 MEDICAL IMAGING II}

649816 Simultaneous surface and volume registration using harmonic maps [6498-49]

A. A. Joshi, Univ. of Southern California (USA); D. W. Shattuck, P. M. Thompson, Univ. of California, Los Angeles (USA); R. M. Leahy, Univ. of Southern California (USA)

649817 Regional approach to fMRI data analysis using hemodynamic response modeling [6498-37]

L. Liu, A. A. Rao, Purdue Univ. (USA); T. M. Talavage, Purdue Univ. (USA) and Indiana Univ. School of Medicine (USA)

649818 Fast joint estimation of local magnitude, decay, and frequency from single-shot MRI [6498-38]

W. Tang, S. J. Reeves, Auburn Univ. (USA); D. B. Twieg, The Univ. of Alabama, Birmingham (USA)

\section{SESSION 12 MEDICAL IMAGING III}

649819 High-resolution image reconstruction for PET using estimated detector response functions [6498-39]

M. S. Tohme, J. Qi, Univ. of California, Davis (USA)

$64981 \mathrm{~A} H i g h$ resolution projection reconstruction MR imaging using FOCUSS [6498-40]

S. Tak, J. Yoo, J. C. Ye, Korea Advanced Institute of Science \& Technology (South Korea) 
64981B Non-homogeneous updates for the iterative coordinate descent algorithm [6498-41]

Z. YU, Purdue Univ. (USA); J.-B. Thibault, GE Healthcare Technologies (USA); C. A. Bouman,

Purdue Univ. (USA); K. D. Sauer, Univ. of Notre Dame (USA); J. Hsieh, GE Healthcare

Technologies (USA)

64981C Statistical modelling of the myosin lattice in vertabrate muscle [6498-53]

C. H. Yoon, R. P. Millane, N. D. Blakeley, A. Goyal, Univ. of Canterbury (New Zealand)

\section{SESSION 13}

COLOR IMAGING

64981D Training-based algorithm for moiré suppression in scanned halftone images [6498-55]

H. Siddiqui, C. A. Bouman, Purdue Univ. (USA)

\section{POSTER SESSION}

64981E A computational 3D model for reconstruction of neural stem cells in bright-field time-lapse microscopy [6498-44]

J. Degerman, Chalmers Univ. of Technology (Sweden); E. Winterfors, Univ. Pierre et Marie

Curie (France); J. Faijerson, Sahlgrenska Academy at Göteborg Univ. (Sweden);

T. Gustavsson, Chalmers Univ. of Technology (Sweden)

$64981 \mathrm{~F}$ Empirical evaluation of dissimilarity measures for use in urban structural damage detection [6498-45]

Z. Chen, T. C. Hutchinson, Univ. of California, San Diego (USA)

$64981 G$ Cryo-electron microscopy single particle reconstruction of virus particles using compressed sensing theory [6498-46]

M. W. Kim, J. Choi, L. YU, Korea Advanced Institute of Science and Technology (South

Korea); K. E. Lee, S.-S. Han, Korea Univ. (South Korea); J. C. Ye, Korea Advanced Institute of Science and Technology (South Korea)

64981 $\mathrm{H}$ GPU-based visualization techniques for 3D microscopic imaging data [6498-47]

Q. Wang, Y. Sun, J. P. Robinson, Purdue Univ. (USA)

649811 GICEB: automatic segmentation algorithm for biomedical images [6498-48]

Q. Wang, N. Vaidhyanathan, F. Vadakkumpadan, Y. Sun, Purdue Univ. (USA)

Author Index 
Downloaded From: https://www.spiedigitallibrary.org/conference-proceedings-of-spie on 26 Apr 2023

Terms of Use: https://www.spiedigitallibrary.org/terms-of-use 


\title{
Conference Committee
}

\author{
Symposium Chairs \\ Michael A. Kriss, Consultant (USA) \\ Robert A. Sprague, Consultant (USA) \\ Conference Chairs
}

Charles A. Bouman, Purdue University (USA)

Eric L. Miller, Northeastern University (USA)

llya Pollak, Purdue University (USA)

Program Committee

Samit K. Basu, GE Global Research (USA)

Thomas S. Denney, Jr., Auburn University (USA)

Peter C. Doerschuk, Purdue University (USA)

Peyman Milanfar, University of California, Santa Cruz (USA)

Joseph A. O'Sullivan, Washington University in St. Louis (USA)

Zygmunt Pizlo, Purdue University (USA)

Stanley J. Reeves, Auburn University (USA)

Yongyi Yang, Illinois Institute of Technology (USA)

Yibin Zheng, University of Virginia (USA)

Session Chairs

1 Medical Imaging I

Eric L. Miller, Northeastern University (USA)

2 Mosaicing, Interpolation, Super-resolution

Mary L. Comer, Purdue University (USA)

3 Segmentation and Shape Analysis

llya Pollak, Purdue University (USA)

4 Compression and Compressed Sensing

Rebecca M. Willett, Duke University (USA)

5 Hardware Systems for Imaging and Tomography

Samit K. Basu, GE Global Research (USA)

6 Restoration, Filtering, and Reconstruction

Peyman Milanfar, University of California, Santa Cruz (USA) 
$7 \quad$ Tracking, Recognition, and Scene Analysis

Zygmunt Pizlo, Purdue University (USA)

$8 \quad$ Multigrid Methods

Charles A. Bouman, Purdue University (USA)

$9 \quad$ Imaging in Materials Science

Charles A. Bouman, Purdue University (USA)

10 Reconstruction, Inpainting, and Prediction

Minh N. Do, University of Illinois at Urbana-Champaign (USA)

11 Medical Imaging II

Thomas Talavage, Purdue University (USA) 